\title{
Effect of Lactobacillus fermentum Fermentation on the Nutritional and Anti-Nutritional Quality of Sorghum (Samsorg 17) for Chicken Feed Production
}

\author{
Aliyu Isah Moriki ${ }^{1, ~ *}$, Mohammed Sani Sambo Datsugwui ${ }^{2}$, Abubakar Attahiru ${ }^{3}$ \\ ${ }^{1}$ Department of Biology, Zamfara Collage of Arts and Science, Gusau, Nigeria \\ ${ }^{2}$ Department of Microbiology, Nile University, Abuja, Nigeria \\ ${ }^{3}$ National Biotechnology Development Agency, Kano, Nigeria
}

Email address:

aliyumoriki@gmail.com (A. I. Moriki)

${ }^{*}$ Corresponding author

\section{To cite this article:}

Aliyu Isah Moriki, Mohammed Sani Sambo Datsugwui, Abubakar Attahiru. Effect of Lactobacillus fermentum Fermentation on the Nutritional and Anti-Nutritional Quality of Sorghum (Samsorg 17) for Chicken Feed Production. International Journal of Bioorganic Chemistry. Vol. 4, No. 2, 2019, pp. 93-97. doi: 10.11648/j.ijbc.20190402.12

Received: November 27, 2019; Accepted: December 18, 2019; Published: December 25, 2019

\begin{abstract}
The effect of fermentation using Lactobacillus fermentum (Lactic acid bacteria) on the nutritional content, antinutrient quality of sorghum (samsorg 17) was investigated. Sorghum sample was subjected to three days (72 hours) submerged fermentation during which the Lactobacillus fermentum was inoculated using 0.5 Mcfarland standard. $\mathrm{pH}$ and TTA was recorded after every 12 hours though out the 72 hours of the fermentation. There was decrease in $\mathrm{pH}$ with increase in TTA as the fermentation time progresses. The result of the proximate analysis revealed a marginal increase in percentage protein content for fermented sorghum sample (7.89 to $11.50 \%$ ). There was increase in moisture content and decrease in carbohydrate, ash content and fat contents of the fermented sorghum sample. Results from this research also showed significant reduction in anti-nutritional content which are tannin and phytate. Fermentation has modified the nutritional quality and anti-nutritional quality of sorghum and this has greatly improved the nutrient content of the sorghum.
\end{abstract}

Keywords: Fermentation, Lactobacillus fermentum, Sorghum, Tannin and Phytate

\section{Introduction}

Fermentation is an age long method of processing cereals and legumes. It modifies some physical characteristics of cereals and legumes, increases the level of some nutrients, digestibility and bioavailability, decreases levels of antinutrients, increases nutrient density and imparts some antimicrobial property [1]. Lactic acid Bacteria (LAB) is important bacteria in fermented products, it is functioned both in fermentation process or increasing nutrient value of fermented products. LAB is a gram-positive, non sporing, catalase negative, devoid of cytochromes, of nonaerobic habit but aerotolerant, fastidious, acid tolerant and strictly fermentation [2]. LAB have been extensively used in food fermentation, including the production of dairy products, and its proteolitic activity is very important in producing flavor compounds of end product [3].

Sorghum (Sorghum bicolor) is a drought resistant cereal that is produced worldwide. Sorghum is the fifth most important crop after wheat, rice, corn, and barley [4]. However, in West Africa sorghum is the 2nd most important cereal grain after millet and just before corn. Also, sorghum is the primary alternative feedstuff for corn in the U.S., Central America, South America, and Asia and for wheat in Australia. In contrast to corn use in the Americas, in Africa and India sorghum is a staple food used secondarily as feed $[5,6]$. Major sorghum producing countries are the U.S., India, Nigeria, Mexico, China, Sudan, Argentina, and Australia. Worldwide the area planted to sorghum steadily increased from 24 to 46 million hectors between 1950 and 1980, but has decreased and stagnated at 41 million hectors for the past 20 years. Globally average yield increased from 0.57 to 1.48 metric tons/ha (260\%) from 1950 to 2000 
whereas the sorghum yield in the U.S. averaged 4.4 metric tons/hector during that same time period. From 1992 to 1994 Africa was producing 17.1 million metric tons $(27 \%$ of the world's production) on 21.8 million ha (48\% of the world's planted area) (5). Sorghum bicolor is widely grown in the semi-arid and arid savannah regions of Nigeria. [5] reported that sorghum is a traditional crop of much of Africa and Asia and an introduced and hybridized crop in the western hemisphere. It benefits from an ability to tolerate drought, soil toxicities and temperature extremes effectively than other cereals. In terms of the nutritive value, cost and availability, sorghum grain is the next alternative to maize in poultry feed [7]. However, the diversity of chemical composition and antinutritional factors, mainly tannin resulting in variability in digestibility from $35-60 \%$ or more have been reported. Varieties of sorghum, climatic and soil conditions, fertilizer types are listed among the factors responsible for the variations in chemical composition of sorghum [8, 9]. The aim of this work is to evaluate the effect of fermentation using lactobacillus fermentum on the nutritional quality of sorghum

\section{Materials and Methods}

\subsection{Collection of Samples}

The sorghum (Samsorg 17) sample was obtained from Institute of Agricultural Research Zaria. Lactic acid bacteria (Lactobacillus fermentum) was isolated and characterized in Food and Industrial Microbiology Laboratory, Kaduna State University.

\subsection{Fermentation of Sorghum}

The sorghum was packed in air tight bottles and sealed into autoclave and sterilized at $121^{\circ} \mathrm{C}$ for 15 minutes, it was allowed to cool to room temperature before inoculation. Submerged fermentation method was employed; Lactobacillus fermentum was inoculated using 0.5 Mcfarland standard and allow to ferment at $37^{\circ} \mathrm{C}$ for 72 hours [10]

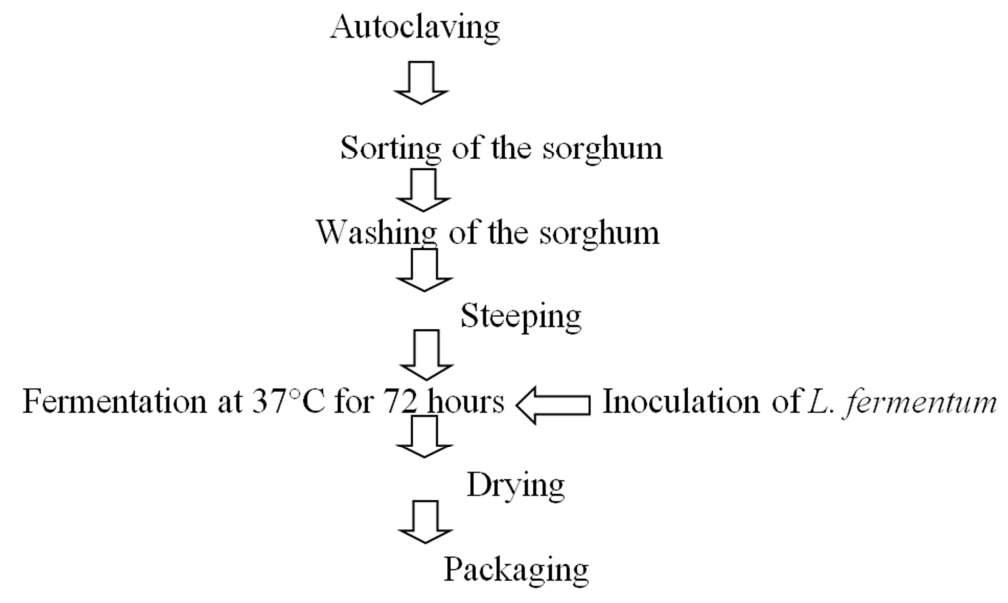

Figure 1. Flow chart for the fermentation of sorghum [11].

2.3. Physicochemical Analysis of Sorghum (pH and Total Titratable Acidity During Three Days Fermentation of Sorghum (Samsorg 17) Inoculated with Lactobacillus fermentum and the Natural Fermentation (Control)

The changes in $\mathrm{pH}(\mathrm{pH}$ meter - Surgifield medical England Sm - 6021A) and total titratable acidity (TTA) of fermenting samples were monitored for every 12 hours till the end of fermentation [10].

\subsection{Proximate Composition of Fermented and Unfermented Sorghum}

The proximate chemical composition of sorghum samples was determined using the standard procedures of Association of Official Analytical Chemist AOAC (2005) before and after fermentation [12]

\subsection{Anti-Nutrients Determination of Fermented and Unfermented Sorghum}

The Tannin and phytate composition of fermented and unfermented sorghum samples of was determined using the procedure described by [13] before and after fermentation.

\section{Results and Discussion}

Tables 1 and 2 showed $\mathrm{pH}$ and TTA readings during the 3 days' fermentation of sorghum (Samsorg 17) inoculated with Lactobacillus fermentum and the control respectively. Fermentation was observed to reduce the $\mathrm{pH}$ from $4.90 \pm 0.60$ to $4.57 \pm 0.40$ and increase the total titratable acidity from $4.37 \pm 0.35$ to $3.83 \pm 0.50$ of the fermented sorghum from 12 hours to 72 hours of fermentation.

The observed increase in titratable acidity could be due to the dominance of the environment by lactic acid bacteria which degrades carbohydrates resulting in acidification. These observations are in agreement with earlier studies by [13]. The observed decrease in $\mathrm{pH}$ as the fermentation progressed (4.90-3.83) was possibly because of the accelerated growth of the lactic acid bacteria. This is in agreement with [14] who reported a decrease in $\mathrm{pH}$ as the 
fermentation progressed (5.75-3.26). The $\mathrm{pH}$ trend of 4.903.83 as the fermentation progressed is also in agreement with the work of [1] who reported decrease in $\mathrm{pH}$ as the fermentation time progressed. [11] revealed that Lactic acid fermentation gives fermented foods a sour taste and lowers the $\mathrm{pH}$ of the food, [11] further revealed a rapid drop in $\mathrm{pH}$ for lactic acid fermentation of various food grains was observed. [15] studied three selected cereals sorghum, rice and maize when fermented resulted in a decrease in $\mathrm{pH}$ for all cereal.

The results of the proximate analysis of fermented and unfermented sorghum is represented in table 3. Unfermented sorghum had higher percentage of ash content, fat content, total carbohydrates and total energy while the fermented sorghum had higher percentage protein content and moisture content.

The percentage ash content was found to higher in unfermented sorghum $1.20 \pm 0.21$ and with a significantly different $(\mathrm{P}<0.05)$ compared to the ash content obtained in the fermented sorghum $0.93 \pm 0.08$. The percentage fat content of the unfermented sorghum was $4.57 \pm 0.43$ which had higher and significantly different $(\mathrm{P}<0.05)$ compared to the fermented sorghum with $0.37 \pm 0.06$. Unfermented sorghum had $79.29 \pm 0.73$ percentage carbohydrates content which is significantly different $(\mathrm{P}<0.05)$ compared to the fermented sorghum which had $77.74 \pm 0.46$. The total energy was higher in unfermented sorghum with $389.69 \pm 4.76 \mathrm{kcal} / \mathrm{g}$ when compared with the value obtained in fermented sorghum with $360.29 \pm 4.46 \mathrm{kcal} / \mathrm{g}$. The percentage moisture content in fermented sorghum was higher with the value of $9.46 \pm 0.73$ which is significantly different $(\mathrm{P}<0.05)$ compared with the value of unfermented sorghum which had 7.05 \pm 0.81 . The percentage protein content was higher in fermented sorghum with $11.50 \pm 0.95$ and significantly different $(\mathrm{P}<0.05)$ compared to the value of the unfermented sorghum with $7.89 \pm 0.97$ (Table 3)

At the end of fermentation, protein content was observed to increase for fermented sorghum. This is in agreement with the reports of $[16,17]$ who reported that fermentation significantly increased protein content of sorghum. [18, 19] reported a marginal increase in protein content of fermented sorghum. This increase can be attributed to the loss of dry matter mainly carbohydrates or due to the action of extracellular enzymes produced by the fermenting microorganisms [13]. The increase in protein contents agrees with the work of [20] who reported that the use of fermentation may prove a means of improving product functionality and protein contents. [16] revealed that there was increase in protein content after fermentation and this increase in protein content could be due to the activities and increase in number of lactic acid bacteria present during fermentation. The increase in protein contents agrees with the findings of [20] who reported that the use of fermentation may prove a means of improving product functionality and protein contents. Many investigators have reported that fermentation can be effectively be used for improving nutritional quality of cereal grain by increasing protein content and digestibility [14, 18].

There was decrease in fat content after fermentation of sorghum for fermented sorghum. The decrease may be attributed to the breakdown of fatty acid and glycerol by lipolitic organisms present in the sample during fermentation. The break down resulted in the increase of Aroma, taste, odour and texture of fermented sample $[1,21]$. Reduction in the lipid content increased the shelf life of food sample. Fermentation improves the fat content, these may be due to an increased activity of the lipolytic enzymes in the fermentation medium which hydrolyzed fat to glycerol and fatty acid [13].

The carbohydrate content was observed to reduce in unfermented sorghum. The reduction in carbohydrate levels agrees with the reports of [1] who revealed that carbohydrate level during fermentation reduces because of the activities of the fermenting microbes. [1, 22] also reported decrease in carbohydrate content during fermentation of starchy substrates. This decrease could be attributed to increase activity of $\alpha$-amylase which hydrolyses starch to simple sugar, the sugar provides a source of energy for the fermenting microorganisms [13]. This reduction in carbohydrate content was due to the utilization of some of the sugars by fermenting lactic acid bacteria for growth and other metabolic activities. The decrease may also be attributed to conversion of carbohydrate to glucose and use by fermenting microorganism as energy source [20].

Contrary to expectation, the ash content was also reduced with fermentation. This could be due to the leaching of some of the inorganic matter into the aqueous medium used for the fermentation, fermentation improved the gross energy value of the seed [13].

Table 4 revealed the level of anti-nutritional factors found in the fermented and unfermented sorghum. Based on tannin content, unfermented sorghum had $1.65 \pm 0.27$ and is significantly $(p<0.05)$ different compared to the value obtained for fermented sorghum which is $1.15 \pm 0.20$. In phytate content, unfermented sorghum had $0.14 \pm 0.01$ and is significantly $(p<0.05)$ different compared to the value obtained for fermented sorghum which is $0.09 \pm 0.01$

The tannin level of the fermented sorghum was observed to decrease; this may be due to their binding with cotyledon endosperm that are usually undetected by routine method due to their insolubility in solvent [23] or may be due to microbial phenyl oxidase action. Tannin content was reported to decrease during natural lactic acid fermentation in sorghum, and maize [24].

The observed decrease in tannin content of fermented sorghum is in agreement with [19] who reported that up to 14 $\mathrm{g} / \mathrm{kg}$ tannins had no significant negative effect on broiler growth. This is similar to the findings of [23] reported more sodium $(\mathrm{Na})$ excretion by broilers fed high phytate diets. Phytate was observed to decrease for fermented sorghum, these findings are in conformity with reports of [24, 25] who reported that phytic acid content significantly $(\mathrm{P}<0.05)$ decreases from 647.0 to $310.95 \mathrm{mg} / 100 \mathrm{~g}$ (51.9\% reduction) after fermentation. 
Table 1. pH during 3 days Fermentation of Sorghum (Samsorg 17) inoculated with Lactobacillus fermentum and the Natural Fermentation (control).

\begin{tabular}{lll}
\hline \multirow{2}{*}{ Fermentation time } & $\mathbf{p H}$ reading & \multirow{2}{*}{ Control } \\
\cline { 2 - 3 } & Inoculated sorghum & \\
\hline 12 hours & $4.90 \pm 0.60^{\mathrm{b}}$ & $4.37 \pm 0.35^{\mathrm{a}}$ \\
24 hours & $4.87 \pm 0.50^{\mathrm{b}}$ & $4.22 \pm 0.50^{\mathrm{a}}$ \\
36 hours & $4.80 \pm 0.50^{\mathrm{b}}$ & $4.11 \pm 0.30^{\mathrm{a}}$ \\
48 hours & $4.78 \pm 0.30^{\mathrm{b}}$ & $3.92 \pm 0.50^{\mathrm{a}}$ \\
60 hours & $4.59 \pm 0.40^{\mathrm{b}}$ & $3.91 \pm 0.50^{\mathrm{a}}$ \\
72 hours & $4.57 \pm 0.40^{\mathrm{b}}$ & $3.83 \pm 0.50^{\mathrm{a}}$ \\
\hline
\end{tabular}

Values are Mean $\pm \mathrm{SD}$; Values with different superscript across the rows are significantly different $(\mathrm{P}<0.05)$

Table 2. Total Titratable Acidity (TTA) during 3 days Fermentation of Sorghum (Samsorg 17) inoculated with Lactobacillus fermentum and the control.

\begin{tabular}{|c|c|c|}
\hline \multirow{2}{*}{ Fermentation time } & TTA Reading & \multirow{2}{*}{ Control } \\
\hline & Inoculated sorghum & \\
\hline 12 hours & $0.126 \pm 0.003^{\mathrm{a}}$ & $0.144 \pm 0.002^{b}$ \\
\hline 24 hours & $0.180 \pm 0.006^{\mathrm{a}}$ & $0.171 \pm 0.004^{\mathrm{a}}$ \\
\hline 36 hours & $0.198 \pm 0.003^{\mathrm{a}}$ & $0.225 \pm 0.008^{b}$ \\
\hline 48 hours & $0.225 \pm 0.005^{\mathrm{a}}$ & $0.234 \pm 0.002^{b}$ \\
\hline 60 hours & $0.252 \pm 0.005^{\mathrm{a}}$ & $0.270 \pm 0.003^{b}$ \\
\hline 72 hours & $0.315 \pm 0.003^{\mathrm{b}}$ & $0.288 \pm 0.002^{\mathrm{a}}$ \\
\hline
\end{tabular}

Values are Mean $\pm \mathrm{SD}$; Values with different superscript across the rows are significantly different $(\mathrm{P}<0.05)$

KEY

Inoculated sorghum; sorghum inoculated with starter culture (Lactobacillus fermentum) Control; sorghum not inoculated with starter (Natural fermentation)

Table 3. Proximate Composition of Fermented and Unfermented Sorghum.

\begin{tabular}{lll}
\hline Parameters & $\begin{array}{l}\text { Unfermented } \\
\text { sorghum }\end{array}$ & Fermented sorghum \\
\hline \% Moisture & $7.05 \pm 0.81^{\mathrm{a}}$ & $9.46 \pm 0.73^{\mathrm{b}}$ \\
$\%$ Ash & $1.20 \pm 0.21^{\mathrm{b}}$ & $0.93 \pm 0.08^{\mathrm{a}}$ \\
\% Fat & $4.57 \pm 0.43^{\mathrm{b}}$ & $0.37 \pm 0.06^{\mathrm{a}}$ \\
\% Protein & $7.89 \pm 0.97^{\mathrm{a}}$ & $11.50 \pm 0.95^{\mathrm{b}}$ \\
\% Total Carbohydrates & $79.29 \pm 0.73^{\mathrm{b}}$ & $77.74 \pm 0.46^{\mathrm{a}}$ \\
Total energy kcal/g & $389.69 \pm 4.76^{\mathrm{b}}$ & $360.29 \pm 4.46^{\mathrm{a}}$ \\
\hline
\end{tabular}

Values are Mean $\pm \mathrm{SD}$; Values with different superscript across the rows are significantly different $(\mathrm{P}<0.05)$

Table 4. Anti-nutritional Composition of Unfermented Sorghum and Fermented Sorghum Grains.

\begin{tabular}{lll}
\hline Parameters & $\begin{array}{l}\text { Unfermented } \\
\text { sorghum }\end{array}$ & Fermented sorghum \\
\hline Tannin & $1.65 \pm 0.27^{\mathrm{b}}$ & $1.15 \pm 0.20^{\mathrm{a}}$ \\
Phytate & $0.14 \pm 0.01^{\mathrm{b}}$ & $0.09 \pm 0.01^{\mathrm{a}}$ \\
\hline
\end{tabular}

Values are Mean $\pm \mathrm{SD}$; Values with different superscript across the rows are significantly different $(\mathrm{P}<0.05)$

Table 5. Feed Consumption Rate of Broiler Chickens Fed with Three Experimental Feeds (Commercial, Fermented Sorghum and Unfermented Sorghum Feed).

\begin{tabular}{llll}
\hline Weeks & $\begin{array}{l}\text { Commercial feed } \\
\text { group }\end{array}$ & $\begin{array}{l}\text { Fermented feed } \\
\text { group }\end{array}$ & $\begin{array}{l}\text { Unfermented } \\
\text { feed group }\end{array}$ \\
\hline Week 1 & $264.69 \pm 16.22^{\mathrm{b}}$ & $229.01 \pm 11.83^{\mathrm{b}}$ & $162.21 \pm 7.67^{\mathrm{a}}$ \\
Week 2 & $399.44 \pm 23.59^{\mathrm{b}}$ & $333.93 \pm 30.85^{\mathrm{b}}$ & $231.48 \pm 8.23^{\mathrm{a}}$ \\
Week 3 & $642.23 \pm 23.75^{\mathrm{c}}$ & $558.78 \pm 11.18^{\mathrm{b}}$ & $315.72 \pm 11.33^{\mathrm{a}}$ \\
Week 4 & $839.26 \pm 25.90^{\mathrm{c}}$ & $723.80 \pm 22.68^{\mathrm{b}}$ & $396.65 \pm 9.87^{\mathrm{a}}$ \\
\hline
\end{tabular}

\begin{tabular}{llll}
\hline Weeks & $\begin{array}{l}\text { Commercial feed } \\
\text { group }\end{array}$ & $\begin{array}{l}\text { Fermented feed } \\
\text { group }\end{array}$ & $\begin{array}{l}\text { Unfermented } \\
\text { feed group }\end{array}$ \\
\hline Week 5 & $1117.67 \pm 10.82^{\mathrm{c}}$ & $923.37 \pm 20.95^{\mathrm{b}}$ & $527.29 \pm 17.61^{\mathrm{a}}$ \\
Week 6 & $1340.56 \pm 37.41^{\mathrm{c}}$ & $1141.85 \pm 33.46^{\mathrm{b}}$ & $697.06 \pm 24.89^{\mathrm{a}}$ \\
\hline
\end{tabular}

Values are Mean \pm SEM; Values with different superscript across the rows are significantly different $(\mathrm{P}<0.05)$

\section{Conclusions}

Fermentation using Lactobacillus fermentum was observed to modify both nutritional and anti-nutritional qualities of sorghum. The percentage protein content of fermented sorghum was found to be considerably higher than that of unfermented sorghum. Tannin and Phytates of the unfermented sorghum was found to be much higher than that of the fermented sorghum. Fermented sorghum feed performs considerably higher than unfermented sorghum feed, as it impair body weight, feed intake, carcass and organ weights in broiler starter and finisher diets.

\section{References}

[1] Anthony, O. and Babatunde, B. (2014). Effect of Fermentation on Nutrient and Anti-nutrient Composition of Millet (Pennisetum glaucum) and Soyabean (Glycine max) Blend Flours. Journal of Life Sciences, 8 (8); 675-680.

[2] Khalid K. (2011). An overview of Lactic Acid Bacteria. Internatinal Journal of Biosciences pp 1 (3) 1-13.

[3] Moulay, M, K., Benlancen, H A., Kihal, M. (2013). Diversity and Technological Properties of predomonant Lactic Acid Bacteria Isolated from Algerian raw goat milk. Advances in Environmental Biology 7 (6) 999-1007.

[4] Bryden, W. L., Selle, P. H. Cadogan, D. J. Li, X. Muller, N. D. Jordan, D. R. Gidley, M. J. and Hamilton, W. D. (2009). A review of the nutritive value of sorghum in broilers. Rural Industry Development. Corporation. Kingston.

[5] Maunder, A. B. (2002). Sorghum worldwide. Sorghum and Millet Diseases. J. F. Lesile (Ed.). Iowa State Pres, Blackwell Publ. Comp. Ames, Iowa. PP. 11-18.

[6] Abdoulaye, T., Sanders, J., and Ouendeba, B. (2006). Which grain for poultry feed in West Africa: sorghum or corn? Bulletin $\mathrm{N}^{\circ} 4$, Marketing-Processing Project. West Africa, Niamey, Niger. 24.

[7] Subramanian, V, and Metta, V. C (2000). Sorghum grain for poultry feed. In: Technical and Institution Options for Sorghum Grain Mold Management. Proc. International Consultation. Chandrasher A, Bandyopadhayi R and Hall AJ (eds.). International Crop Research for the Semi-Arid Tropics (ICRISAT). pp. 242-247.

[8] Etuk, EB. And Ukaejiofo U. R. (2007). Tannin content and dietary effects of brown coat coloured sorghum on the performance of young local turkey. Animal. Production. Res. $A d v ., 3$ (2): 86-90.

[9] Etuk, EB. (2008). Nutrient composition and feeding value of sorghum for turkeys. PhD Thesis, Federal University of Technology, Owerri, Nigeria pp 88-123. 
[10] Nwachukwu, E., Achi, O. K., Ijeoma I. O. (2010) Lactic acid bacteria in fermentation of cereals for the production of indigenous Nigerian foods. African Journal of Food Science and Technology 1 (2); 21-26.

[11] Asma, A. B. T. (2011) Nutritional quality of fermented sorghum soybean composite flour. Department of food science and Technology University of kharltoum pp 15.

[12] AOAC, (2005). Official Methods for Analysis, 16th ed. Association of Official Analytical.

[13] Apena A., Opeolu S. O., Bamidele. F. A. and Shittu A., (2015). Nutrient changes during fermentation of some selected cereals. Sky Journal of Biochemistry Research. 4 (2), 10-12.

[14] Abedel-Hady, A. S., Hassan, A. B., Ali, I. M., Babiker, E., (2005). Antinutritional factors content and availability of protein, starch and mineral of maize (Zeamays linnanus) and lentil (Lens culinaris) as influenced by domestic processing. Journal of Food Technology. 3; 523-528.

[15] EL Hag, M. E., El Tinay, A. H., Yousif, N. E. (2002). Effect of fermentation and dehulling on starch, total polyphenols, phytic acid and in vitro digestibility of pearl millet. Food Chemistry. 77, 193-196.

[16] Elyas, S. H., El-Tinay, A. H., Yosif, N. E., Elsheikh, E. A. (2002). Effect of fermentation on nutritive value and in vitro protein digestibility of pearl millet. Food Chemistry. 78; 7579.

[17] Inyang, C. U. and Zakari, U. M. (2008). Effect of germination and fermentation of pearl millet on proximate, chemical and sensory properties of instant "Fura-Nigerian cereal food. Pakistan Journal of Nutrition. 7, 9-12.

[18] Ali, A. M., El-Tinay, H. A., Abdalla, H. A. (2003). Effect of fermentation on the in vitro digestibility of pear millet. Journal of Food Chemistry. 80; 51-54.
[19] Hassan, A. B., Mohamed Ahmed, I. A., Osman, N. M., Eltayeb, M. M., Osman, G. A., Babiker, E. E., 2006. Effect of processing treatment followed by fermentation on protein content and digestibility of pearl millet (Pennisetum typhoideum) cultivars. Pakistan Journal of Nutrition. 5 (1), 86-89.

[20] Afoakwa, E. O., Sefa-Deheh, S., Kluvitse, Y., Sakyi-Dawson, E. O. (2004). "The Influence of Fermentation and Cowpea Fortification on the Quality Characteristics of Maize-based Weaning Foods." Presented at the Second International Workshop on Food-based Approaches for Healthy Nutrition in West Africa: The Role of Food Technologists and Nutritionists, Ouagadougou, Burkina Faso. 10 (1): 23-27.

[21] Chang, S., Miles, P. G. (2004). Mushrooms, Cultivation, Nutritional Value, Medicinal Effect and Environmental Impact. Florida: CRC press. Chemists, Arlington VA, USA. 44; 88-90

[22] Oboh, G. and Akindahunsi, A. A. (2003). "Biochemical Changes in Cassava Product (Flour and Garri) Subjected to Saccharomyces cerevisae Solid Media Fermentation." Journal of Food Chemistry, 82: 599-602.

[23] Emambux, M. N., Taylor, J. N., (2003). Sorghum kafirin interaction with various phenolic compounds. Science Journal of food Agriculture. 83; 402407.

[24] Abdel-Haleem, W. H., El Tinay., A. H., Mustafa, A. I., Babiker, E. E. (2008). Effect of fermentation, maltpretreatment and cooking on antinutritional factors and protein digestibility of sorghum cultivars. Pakistan Journal of Nutrition. 7, 335-341.

[25] Kayode, A. P., Hounhougigan, J. D., Nout, M. J. (2007). Impact of brewing process operation on phytate, phenolic compounds and in vitro solubility of iron and zinc in opaque sorghum beer. $40,834-841$. 